\title{
VACCINE-ASSOCIATED MEASLES IN AN 1-YEAR-OLD INFANT
}

$\underline{\text { Meltem Polat }}^{1}$, SelçukYüksel ${ }^{2}$, Bayram Özhan ${ }^{2}$, Dolunay Gürses ${ }^{2}$, Yasemin Coşgun ${ }^{3}$, Gülay Korukoğlu ${ }^{3}$

${ }^{1}$ Pamukkale University School of Medicine, Department of Pediatric Infectious Diseases, Denizli, Turkey

${ }^{2}$ Pamukkale University School of Medicine, Department of Pediatrics, Denizli, Turkey

${ }^{3}$ Public Health Agency of Turkey, Virology Reference and Research Laboratory, Ankara, Turkey

\section{Background}

Vaccine-associated measles has been rarely reported in children. We herein describe a case of vaccine-associated measles illness ocurrred 10 days after administration of the measlesmumps-rubella (MMR) vaccine containing the Enders attenuated Edmonston measles strain.

\section{Case Presentation Summary}

A previously healthy, 1-year-old girl presented to our hospital with the complaints of fever and diffuse maculopapular rash. The patient had received her first dose of MMR vaccine 10 days prior to the onset of rash (figure 1). Since measles is under enhanced surveillance according to the national action plan for measles elimination, an epidemiological investigation was initiated, and serum, urine and throat swab specimens for laboratory testing were obtained. The investigation found no similar cases among contacts of the patient.
Measles virus infection was confirmed by both the detection of the measles-specific Ig M by ELISA method (Enzygnost ${ }^{\circledR}$; Siemens, Germany) and the measles virus RNA in throat swab and urine specimen using real-time RTPCR (Applied Biosystems). The measles virus was subsequently determined to be the vaccine strain by sequence analysis of the genome. The patient was discharged from hospital in a good condition on hospital day 10.

\section{Learning Points/Discussion}

In order to maintain the accuracy of the measles surveillance system, it is critical to discriminate between measles vaccine and wild-type virus. Virus genotyping can be used to differentiate between wild-type and vaccine virus infection in those who have been immunized recently.

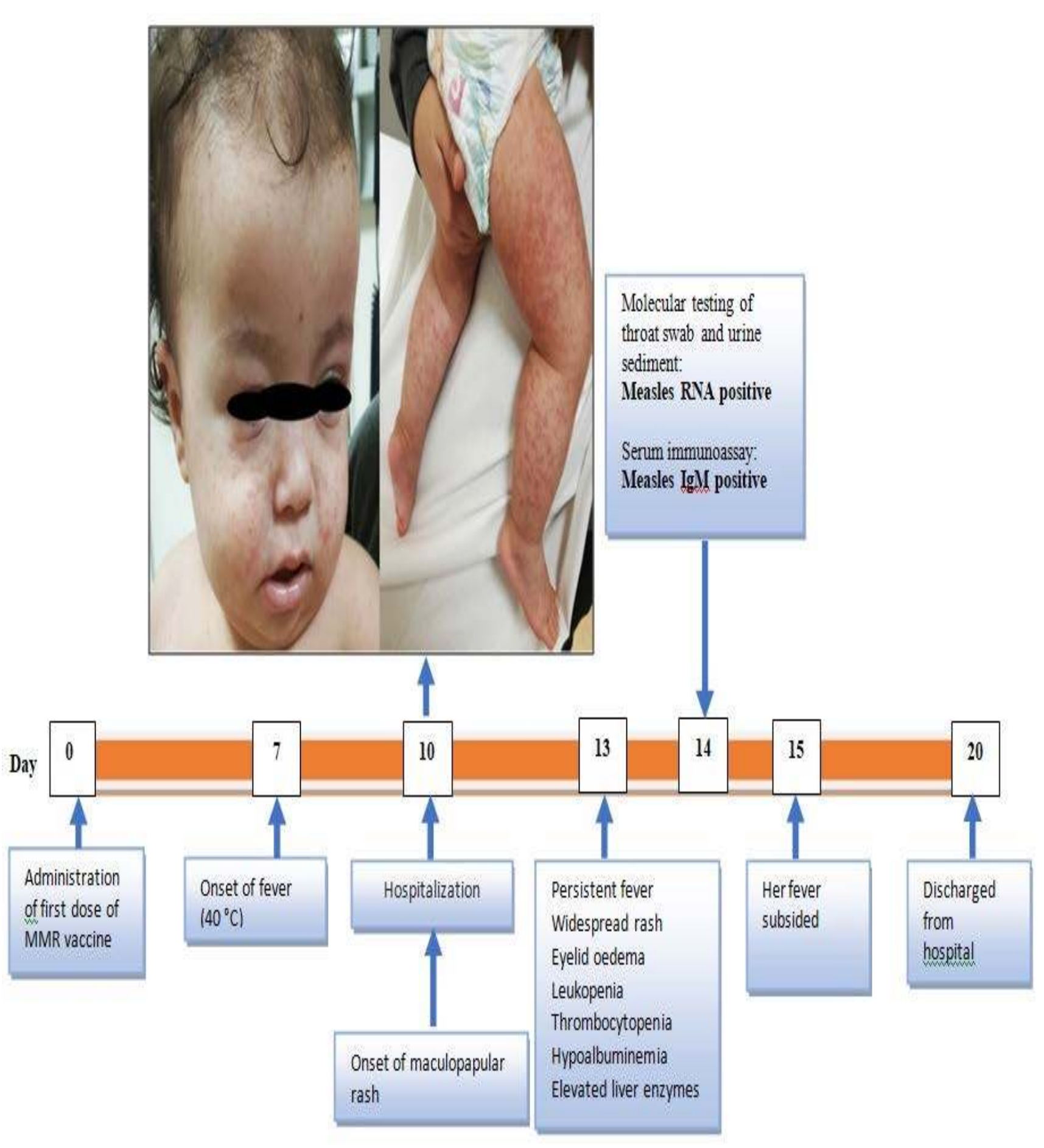

Figure 1. Time line of symptoms, physical signs, and laboratory results in a child with post-vaccine measles 